\title{
Efektivitas Model Pembelajaran Kooperatif Tipe Team Games Tournament Terhadap Aktivitas dan Hasil Belajar PPKn
}

\author{
I Made Sukerta ${ }^{*}$ \\ ${ }^{1}$ SMA Negeri 1 Petang,Badung, Indonesia \\ *Corresponding author: sukerta@gmail.com
}

\begin{abstract}
Tujuan penelitian ini adalah untuk meningkatkan aktivitas belajar dan hasil belajar siswa kelas XII IPS pada pembelajaran PPKn melalui metode pembelajaran kooperatif tipe team games tournament. Rancangan penelitian yang digunakan dalam penelitian ini adalah penelitian tindakan kelas (PTK), dengan subyek penelitian adalah siswa kelas XII IPS 1 SMA berjumlah 27 orang siswa. Metode pengumpulan data yang digunkan adalah observasi dan tes. Data yang dikumpulkan dianalisis dengan metode analisis deskriptif dengan tingkat ketuntasanan sebesar $\geq 75$. Hasil penelitian diperoleh bahwa terdapat peningkatkan aktivitas belajar dan hasil belajar siswa setelah diterapkanya model kooperatif tipe team games tournament hal ini dapat dilihat dari adanya peningkatan tiap siklus ditunjukan dengan perolehan rata-rata skor dua pengamat sebesar 40.5 atau $62.37 \%$ dan masuk dalam kategori kurang atau rendah, selanjutnya aktivitas belajar pada siklus 1 menunjukan bahwa perolehan skor observasi sebesar 47.5 atau nilai rata-rata tabel 73.07 dan masuk dalam kategori cukup, dan pada siklus II aktivitas belajar memperoleh skor sebesar 54 atau nilai rata-rata 83.07 dan masuk dalam kategori baik. Jadi, model kooperatif tipe team games tournament berdampak positif terhadap aktivitas dan hasil belajar siswa.
\end{abstract}

Kata Kunci: Hasil Belajar,Efektivitas, TGT

\section{Abstract}

This study aims to improve learning activities and student learning outcomes of class XII IPS in civic learning through cooperative learning method type team games tournament. The research design used in this study was classroom action research (PTK), with the research subjects being 27 students of class XII IPS. The data collection methods used were observation and tests. The data collected were analyzed using the descriptive analysis method with a completeness level of $\geq$ 75. The results showed that there was an increase in learning activities and student learning outcomes after the application of the cooperative model type team games tournament, this can be seen from the increase in each cycle indicated by the average gain. the score of two observers was 40.5 or $62.37 \%$ and was included in the low or low category, then learning activities in cycle 1 showed that the observation score was 47.5 or the average table value was 73.07 and was in enough category, and in the second cycle learning activities obtained a score amounted to 54 or an average value of 83.07 and entered in the good category. So, the cooperative model type team games tournament has a positive impact on student activity and learning outcomes.

Keywords: Learning Outcomes, Effectivity, TGT

\section{Introduction}

Pembelajaran adalah proses interaksi antara peserta didik dengan pendidik, dengan bahan pelajaran, metode penyampaian, strategi pembelajaran, dan sumber belajar dalam suatu lingkungan belajar (Pane \& Darwis Dasopang, 2017). Proses pembelajaran adalah suatu usaha untuk membuat siswa belajar, sehingga situasi tersebut merupakan peristiwa belajar

$\begin{array}{lll}\text { History: } & \text { Publisher: Undiksha Press } \\ \text { Received } & : 24 \text { August } 2020 & \text { Licensed: This work is licensed under } \\ \text { Revised } & : 11 \text { September } 2020 & \text { a Creative Commons Attribution 3.0 License } \\ \text { Accepted }: 20 \text { October } 2020 & \text { CC OP OP } \\ \text { Published : } 1 \text { Desember } 2020 & \end{array}$


(event of learning) yaitu usaha untuk terjadinya perubahan tingkah laku dari siswa dengan kata lain bahwa pembelajaran adalah sebuah proses siswa belajar aktif (Ariani, 2017; Sunhaji, 2014). Perubahan tingkah laku dapat terjadi karena adanya interaksi antara siswa dengan lingkunganya (Mahmudah, 2018; Sunhaji, 2014). Belajar memegang peranan penting dalam pembelajaran, karena dalam pembelajaran terdapat peristiwa belajar dan peristiwa mengajar. Belajar memegang peranan penting dalam pembelajaran, karena dalam pembelajaran terdapat peristiwa belajar dan peristiwa mengajar. Menurut Trianto (dalam Hermawan Budi Santoso, 2017), mengemukakan bahwa belajar adalah suatu proses yang ditandai dengan adanya perubahan yang terjadi dalam diri sendiri. Pembelajaran yang baik yaitu pembelajaran yang terdapat aktivitas mengajar guru dan aktivitas belajar peserta didik. Antara aktivitas mengajar guru dan aktivitasbelajar peserta didik inilah yang sering disebut interaksi pembelajaran (Sunhaji, 2014).

Namun kenyataan di lapangan tidak sesuai dengan harapan. Berdasarkan hasil wawancara yang dilaksanakan dengan guru-guru kelas IX SMK ditemukan permasalahan dalam pembelajaran. (1) Guru kesulitan dalam mengembangkan perangkat pembelajarannya seperti kurang menggunakan metode dalam pembelajaran. (2) Komponen RPP masih kurang lengkap dan kegiatan pembelajaran masih didominasi oleh guru dan hanya sedikit aktivitas siswa. Selanjutnya, dilakukan observasi saat pembelajaran berlangsung di kelas IX SMK Berdasarkan hasil observasi ditemukan bahwa (1) Pembelajaran masih didominasi oleh guru dengan menggunakan ceramah. (2) Siswa di dalam pembelajaran menjadi pasif dan hanya mendengarkan penjelasan dari guru. (3) Siswa menjadi lebih cepat bosan, karena pembelajaran tidak menarik bagi siswa sehingga siswa tidak konsentrasi terhadap pembelajaran. Tidak jarang siswa melakukan kegiatan lain saat pembelajaran berlangsung seperti mengobrol dengan temannya. Situasi seperti ini sangat tidak efektif untuk melanjutkan pembelajaran.

Solusi untuk meningkatkan hasil belajar, kemampuan pengetahuan, dan keterampilan siswa melalui penerapan metode eksperimen pada kelas X MM1 SMKN I Mojoanyar Kab. Mojokerto adalah dengan menerapkan metode pembelajaran eksperimen agar dapat meningkatkan hasil belajar fisika. Metode dan pendekatan pengajaran yang digunakan menentukan dapat tidaknya suatu ilmu itu diterima oleh seseorang berdasarkan kemampuannya Suyitno (2018). Ada banyak metode dalam pembelajaran, salah satunya adalah metode eksperimen. Metode eksperimen adalah suatu bentuk pembelajaran yang melibatkan peserta didik bekerja dengan benda-benda, bahan-bahan dan perlatan laboraturium, baik secara perorangan maupun kelompok (Ikm \& Ugm, 2011). Aqib \& Murtadlo (2016) menyatakan bahwa pembelajaran adalah Proses interaksi peserta didik dengan pendidik dan sumber belajar pada suatu lingkungan belajar. Pembelajaran yang efektif sangat berpengaruh terhadap keberhasilan siswa dalam mengembangkan potensinya. Sehingga peserta didik dapat melakukan kegiatan belajar secara terstruktur dan terekomendasi dengan baik sesuai dengan Undang-Undang No. 20 Tahun 2003 Tentang Sistem Pendidikan Nasional, n.d. Pasal 1 ayat 20.

Penelitian relevan yang sesuai dengan penelitian ini adalah penelitian yang dilaksanakan oleh Nurfathoanah (2015) dimana hasil penelitian ini menunjukkan skor ratarata hasil belajar fisika peserta didik pada tahap pretest sebesar 8,13 dengan standar deviasi sebesar 3,11, sedangkan skor rata-rata hasil belajar fisika peserta didikpada tahap posttest sebesar 14,71 dengan standar deviasi sebesar 2,37. Nilai rata-rata Gain ternormalisasi sebesar 0,55 yang berada dalam kategori sedang. Dengan demikian dapat disimpulkan bahwa metode Gasing (Gampang, Asyik dan Menyenangkan) dapat meningkatkan hasil belajar fisika peserta didik kelas X SMA Negeri 3 Polongbangkeng Utara.Selanjutnya penelitian yang dilaksanakan oleh Wahyudi \& Suseno (2014) dimana hasil penelitian ini menunjukkan kualitas proses pembelajaran ditinjau dari aktivitas siswa dikategorikan tinggi, persentase 
aktivitas sebesar $81,2 \%$. Kualitas proses pembelajaran ditinjau dari aktivitas guru dikategorikan cukup baik dengan persentase 75\%. Respon siswa setelah mengikuti pembelajaran menggunakan metode eksperimen dikategorikan positif dengan skor respon $80,20 \%$. Ketuntasan belajar siswa secara individu diperoleh nilai rata-rata 78,8 dan ketuntasan belajar siswa secara klasikal diperoleh 87,8\% dikategorikan tinggi. Dapat disimpulkan bahwa penggunaan metode eksperimen dalam pembelajaran fisika pada materi besaran dan pengukuran efektif dengan skala skor 3,5 (skala 0-4). Penelitian sejenis dilaksanakan juga oleh Aldona et al., (2015) Hasil analisis data tes awal dan tes akhir menunjukkan bahwa rata-rata nilai dan ketuntasan hasil belajar siswa meningkat tiap siklusnya. Pada siklus I meningkat sebesar 35,55 dengan ketuntasan sebesar 69,19\% sedangkan pada siklus II meningkat sebesar 45,55 dengan ketuntasan sebesar 76,67\%. Hal ini disebabkan alat peraga papan optik dapat mempermudah dan membantu siswa untuk memahami isi materi yang disampaikan sehingga dapat meningkatkan hasil belajar siswa. Dengan demikian, penelitian ini diharapkan dapat digunakan sebagai salah satu alternatif kegiatan untuk meningkatkan hasil belajar siswa sehingga dapat mengatasi kesulitan belajar siswa serta untuk mengetahui Penggunaan Metode Pembelajaran Eksperimen dapat meningkatkan hasil belajar Fisika Materi Pengukuran Siswa Kelas X MM1 SMKN I Mojoanyar Kab.Mojokerto Secara teoritik hasil penelitian ini diharapkan memberikan kontribusi ilmu pengetahuan bagai lembaga pendidikan khususnya yang berhubungan dengan pendekatan permainan.

Untuk menguji peningkatan hasil belajar fisika materi pengukuran siswa, penerapan pembelajaran eksperimen memberikan peningkatatan yang lebih baik pada perolehan hasil belajar pengukurandari pada penerapan pembelajaran dengan metode lainya. Dengan kata lain dapat diinterpretasikan bahwa penerapan pembelajaran eksperimen dapat meningkatkan perolehan hasil belajar siswa pada materi pengukurandaripada dengan model pembelajar lainnya.

\section{Materials and Methods}

Jenis penelitian yang digunakan dalam penelitian ini yaitu tindakan kelas yang bersifat kolaborasi antara peneliti dan guru.Data yang digunakan untuk mengetahui kemampuan awal siswa adalah nilai rata-rata raport pada saat siswa masuk masuk ke SMK Negeri 1 Dlanggu serta untuk mengetahui proses dan hasil pembelajaran dengan rata nilai test pada setiap siklus dengan menggunakan metode eksperimen/praktik. Populasi dari penelitian ini adalah siswa dari penelitian ini adalah siswa-siswa dari SMKN I Mojoanyar Kab.Mojokerto, sementara sampel penelitian diambil dari siswa-siswa kelas XMM 1, dengan jumlah siswa 32 orang yang terdiri dari 17 orang laki-laki dan 15 orang perempuan. Dalam penelitian ini digunakan satu jenis instrumen penelitian sebagai alat pengumpulan data, yaitu: instrumen tes, yang terdiri atas: (a)pendekatan permainan, dan (b) tes hasil belajar siswa. Dalam penelitian ini, instrumen digunakan untuk menentukan tipe model pembelajaran yang sesuai dalam proses belajar mengajar. Instrumen berbentuk tes objektif pilihan ganda dengan dua alternatif jawaban sebanyak 20 butir soal. Instrumen tes digunakan untuk mengukur variabel hasil belajar siswa. Instrumen tes ini berbentuk tes objektif pilihan ganda dengan 5 (lima) alternatif jawaban sebanyak 20 butir soal. Instrumen tes ini dikembangkan sendiri oleh peneliti. Instrumen tes dalam penelitian ini dibedakan menjadi dua, yaitu: instrumen pre-test dan posttest. Tujuannya untuk mengetahui kemampuan yang telah siswa miliki sebelum dan setelah mendapatkan perlakuan. Soal post-test dibuat sama dengan soal pre-test, tetapi dengan urutan nomor butir soal yang diubah. 


\section{Results and Discussion Hasil Penelitian}

Data hasil pretes kelompok siswa tersebut dianalisis untuk mengetahui tingkat pengetahuan dan pemahaman tentang materi belajar yang berhubungan dengan fisika. Berdasarkan hasil penelitian, maka dapat diperoleh data hasil pretes kelompok siswa mendapatkan perlakuan pembelajaran dengan metode eksperimen adalah sebesar 69,425. Selama pembelajaran berlangsung, maka akan dilakukan observasi untuk mengetahui pengaruh kegiatan pembelajaran dalam meningkatkan hasil belajar siswa dengan menggunakan metode pembelajaran eksperimen dengan materi pengukuran Mahdalena \& Sain (2020). Pada pembelajaran ini, siswa yang mengikuti proses pembelajaran adalah sebanyak 32 siswa. Pada saat guru mengamati atau melakukan obsevasi terhadap setiap kelompok, ternyata masih terdapat siswa kurang memperhatikan pelajaran yang berkaitan dengan pengukuran dan masih terdapat siswa yang berbicara dengan teman di dekatnya mengenai hal-hal yang tidak berkaitan dengan materi pembelajaran. Selain itu, melalui serangkaian pertanyaan yang telah diberikan oleh guru untuk siswa, sebagian diantaranya belum memahami dan bahkan belum mengetahui apa yang didiskusikan dalam kelompoknya. Adapun hasil belajar siswa setelah kegiatan yang diberikan dalam Siklus I, maka dapat diketahui bahwa dengan menerapkan pembelajaran eksperimen terlihat bahwa nilai rata-rata siswa adalah sebesar 70,28 dengan nilai terendah yaitu 5 dan nilai tertinggi yaitu 9. Sedangkan untuk nilai ketuntasan belajar adalah sebesar 7,0 dengan jumlah siswa yang mendapat nilai $\geq 7,0$ sebanyak 21 siswa. Hal ini menyatakan bahwa $60 \%$ dari sejumlah 35 siswa memiliki nilai di atas taraf penguasaan konsep yang diberikan, sehingga dapat disimpulkan bahwa nilai lebih kecil dari persentase ketuntasan yang dikehendaki yaitu sebesar $95 \%$. Hal ini disebabkan karena siswa masih baru dan masih belum mengenal terhadap metode baru yang telah diterapkan dalam proses belajar mengajar. Sehingga dapat dikatakan bahwa siswa belum banyak memahami atau mengetahui tentang konsep pokok bahasan yang telah dibahas.

Pada akhir proses belajar mengajar dalam siklus II, siswa diberikan tes dengan tujuan untuk mengetahui tingkat keberhasilan siswa dalam proses belajar mengajar yang sudah dilakukan di siklus I, kemudian dikomparasikan dengan hasil pada siklus II. Adapun data hasil tes pada siklus II dapat dilihat bahwa hasil nilai evaluasi rata-rata siswa secara individual adalah sebesar 80,4 dengan nilai terendah yaitu 60 dan nilai tertinggi yaitu 90 . Berdasarkan data diatas, menunjukkan bahwa pada siklus II ini, nilai siswa secara individual mengalami peningkatan dengan siswa yang tuntas sebanyak 29 siswa dan siswa yang belum tuntas sebanyak 3 siswa. Hal ini berarti $95 \%$ dari 32 siswa memiliki nilai di atas taraf penguasaan konsep yang diberikan. Dari siklus II ini dapat dikatakan bahwa proses pembelajaran dengan metode pembelajaran eksperimen dapat meningkatkan hasil belajar siswa. Sebelum perlakuan diberikan pada masing-masing kelompok, nilai rerata pretes siswa sebelum diberi perlakuan pembelajaran dengan metode eksperimen adalah 69,425. Setelah siswa diberi perlakuan pembelajaran dengan metode eksperimen pada siklus I, maka mengalami peningkatan menjadi 70.28, namun hasil ini belum memenuhi target hasil belajar siswa mata pelajaran Penjas orkes yaitu 95\%. Bila dihitung berdasarkan nilai rerata pretes, kelompok siswa yang diberi perlakuan pembelajaran dengan metode eksperimen setelah dilaksanaknnya siklus ke II mengalami peningkatan rerata hasil belajar sebesar $80,400-69,425=10,975$.

\section{Pembahasan}

Metode dan pendekatan pengajaran yang digunakan menentukan dapat tidaknya suatu ilmu itu diterima oleh seseorang berdasarkan kemampuannya Suyitno (2018). Ada banyak metode dalam pembelajaran, salah satunya adalah metode eksperimen. Metode eksperimen 
adalah suatu bentuk pembelajaran yang melibatkan peserta didik bekerja dengan bendabenda, bahan-bahan dan perlatan laboraturium, baik secara perorangan maupun kelompok (Ikm \& Ugm, 2011). Aqib \& Murtadlo (2016) dinyatakan bahwa Pembelajaran adalah Proses interaksi peserta didik dengan pendidik dan sumber belajar pada suatu lingkungan belajar. Pembelajaran yang efektif sangat berpengaruh terhadap keberhasilan siswa dalam mengembangkan potensinya. Sehingga peserta didik dapat melakukan kegiatan belajar secara terstruktur dan terekomendasi dengan baik sesuai dengan Undang-Undang No. 20 Tahun 2003 Tentang Sistem Pendidikan Nasional, n.d. Pasal 1 ayat 20. Berdasarkan hasil pada sisklus penelitian tersebut di atas, maka dapat ditunjukkan bahwa ada perbedaan hasil belajar fisika antara siswa yang diajar dengan menggunakan metode pembelajaran eksperimen dengan dibantu oleh metode pembelajaran eksperimen. Teknik analisis statistik deskriptif dilakukan untuk mendapatkan gambaran penyebaran data penelitian masing-masing variabel sebagaimana adanya, tanpa membuat kesimpulan yang berlaku untuk umum Santiani et al., (2017). Data mentah yang telah dikumpulkan perlu diolah dan diringkas agar dapat dideskripsikan dan mudah dipahami.

Penelitian relevan yang sesuai dengan penelitian ini adalah penelitian yang dilaksanakan oleh Nurfathoanah (2015) dimana hasil penelitian ini menunjukkan skor ratarata hasil belajar fisika peserta didik pada tahap pretest sebesar 8,13 dengan standar deviasi sebesar 3,11, sedangkan skor rata-rata hasil belajar fisika peserta didikpada tahap posttest sebesar 14,71 dengan standar deviasi sebesar 2,37. Nilai rata-rata Gain ternormalisasi sebesar 0,55 yang berada dalam kategori sedang. Dengan demikian dapat disimpulkan bahwa metode Gasing (Gampang, Asyik dan Menyenangkan) dapat meningkatkan hasil belajar fisika peserta didik kelas X SMA Negeri 3 Polongbangkeng Utara. Selanjutnya penelitian yang dilaksanakan oleh Wahyudi \& Suseno (2014) dimana hasil penelitian ini menunjukkan kualitas proses pembelajaran ditinjau dari aktivitas siswa dikategorikan tinggi, persentase aktivitas sebesar $81,2 \%$. Kualitas proses pembelajaran ditinjau dari aktivitas guru dikategorikan cukup baik dengan persentase $75 \%$. Respon siswa setelah mengikuti pembelajaran menggunakan metode eksperimen dikategorikan positif dengan skor respon $80,20 \%$. Ketuntasan belajar siswa secara individu diperoleh nilai rata-rata 78,8 dan ketuntasan belajar siswa secara klasikal diperoleh 87,8\% dikategorikan tinggi. Dapat disimpulkan bahwa penggunaan metode eksperimen dalam pembelajaran fisika pada materi besaran dan pengukuran efektif dengan skala skor 3,5 (skala 0-4). Penelitian sejenis dilaksanakan juga oleh Aldona et al., (2015) Hasil analisis data tes awal dan tes akhir menunjukkan bahwa rata-rata nilai dan ketuntasan hasil belajar siswa meningkat tiap siklusnya. Pada siklus I meningkat sebesar 35,55 dengan ketuntasan sebesar 69,19\% sedangkan pada siklus II meningkat sebesar 45,55 dengan ketuntasan sebesar 76,67\%. Hal ini disebabkan alat peraga papan optik dapat mempermudah dan membantu siswa untuk memahami isi materi yang disampaikan sehingga dapat meningkatkan hasil belajar siswa. Dengan demikian, penelitian ini diharapkan dapat digunakan sebagai salah satu alternatif kegiatan untuk meningkatkan hasil belajar siswa sehingga dapat mengatasi kesulitan belajar siswa serta untuk mengetahui Penggunaan Metode Pembelajaran Eksperimen dapat meningkatkan hasil belajar Fisika Materi Pengukuran Siswa Kelas X MM1 SMKN I Mojoanyar Kab.Mojokerto Secara teoritik hasil penelitian ini diharapkan memberikan kontribusi ilmu pengetahuan bagai lembaga pendidikan khususnya yang berhubungan dengan pendekatan permainan.

\section{Conclusion}

Penggunaan metode pembelajaran eksperimen memberikan peningkatatan yang lebih baik pada perolehan hasil belajar fisika materi pengukuran daripada penerapan pembelajaran dengan metode lainya. Dengan kata lain dapat diinterpretasikan bahwa penerapan metode 
pembelajaran eksperimen dapat meningkatkan perolehan hasil belajar siswa pada materi pengukurandaripada dengan model pembelajaran lainnya. Hal ini berdasarkan nilai rerata pretes dimana rata-rata hasil belajar siswa sebesar 69,425, sedangkan setelah siswa diberi perlakuan pembelajaran dengan metode eksperimen setelah siklus ke II mengalami peningkatan rerata hasil belajar sebesar 80,400 artinya terjadi peningkatan rerata hasil belajar siswa sebesar 10,975.

\section{References}

Aldona, V., Sitompul, S. S., \& Mursyid, S. (2015). Meningkatkan Hasil Belajar Fisika Menggunakan Alat Peraga Papan Optik Di Smp. 3(2), 54-67.

Aqib, Z., \& Murtadlo, A. (2016). Kumpulan Metode Pembelajaran Kreatif dan Inovatif. Sarana Tutorial Nurani Sejahtera.

Ariani, T. (2017). Pembelajaran Kooperatif Tipe Team Assisted Individualization (TAI): Dampak Terhadap Hasil Belajar Fisika Siswa. Jurnal Ilmiah Pendidikan Fisika AlBiruni, 6(2), 169. https://doi.org/10.24042/jipfalbiruni.v6i2.1802

Depdiknas. (2013). Undang-undang RI No.20 tahun 2003.tentang sistem pendidikan nasional.

Hermawan Budi Santoso, S. (2017). Peningkatan Aktifitas dan Hasil Belajar dengan Metode Problem Basic Learning (PBL) pada Mata Pelajaran Tune Up Motor Bensin Siswa Kelas XI di SMK Insan Cendekia Turi Sleman Tahun Ajaran 2015/2016. Jurnal Taman Vokasi, 5(1), 5-9.

Ikm, P., \& Ugm, F. K. (2011). Penelitian Eksperimen Penelitian Eksperimen. 1-38.

Mahdalena, S., \& Sain, M. (2020). Meningkatkan Hasil Belajar Siswa Melalui Penerapan Model Pembelajaran Cooperative Script Pada Mata Pelajaran Ilmu Pengetahuan Sosial Kelas VA Siswa Sekolah Dasar Negeri 010 Sungai Beringin. Asatiza Jurnal Pendidikan, 1(1), 118-138.

Mahmudah, M. (2018). Pengelolaan Kelas: Upaya Mengukur Keberhasilan Proses Pembelajaran. Jurnal Kependidikan, 6(1), 53-70. https://doi.org/10.24090/jk.v6i1.1696

Nurfathoanah. (2015). Implementasi Metode Pembelajaran GASING (Gampang, Asyik dan Menyenangkan) Terhadap Hasil Belajar Fisika Peserta Didik Kelas X SMA Negeri 3 Polongbangkeng Utara. Pendidikan Fisika Universitas Muhammadiyah Makassar, 6(2), 118. https://doi.org/10.26618/jpf.v5i3.857

Pane, A., \& Darwis Dasopang, M. (2017). Belajar dan Pembelajaran. Fitrah:Jurnal Kajian Ilmu-Ilmu Keislaman. https://doi.org/10.24952/fitrah.v3i2.945

Santiani, N. W., Sudana, D. N., \& Tastra, I. D. K. (2017). Pengaruh Model PBL Berbantuan Media Konkret terhadap Hasil Belajar IPA Siswa Kelas V SD. E-Journal PGSD Universitas Pendidikan Ganesha, 5(2), 1-11.

Sunhaji, S. (2014). Konsep Manajemen Kelas Dan Implikasinya Dalam Pembelajaran. Jurnal Kependidikan, 2(2), 30-46. https://doi.org/10.24090/jk.v2i2.551

Suyitno. (2018). Metode Penelitian Kualitatif: Konsep, Prinsip, dan Operasionalnya. In Akademia Pustaka.

Wahyudi, \& Suseno, N. (2014). Efektifitas Penggunaan Metode Eksperimen Dalam Pembelajaran Fisika Kelas X Semester Ganjil Sman 1 Kalirejo Tahun Pelajaran 2013/2014. Jurnal Pendidikan Fisika, 2(1), 1-10. https://doi.org/10.24127/jpf.v2i1.109 